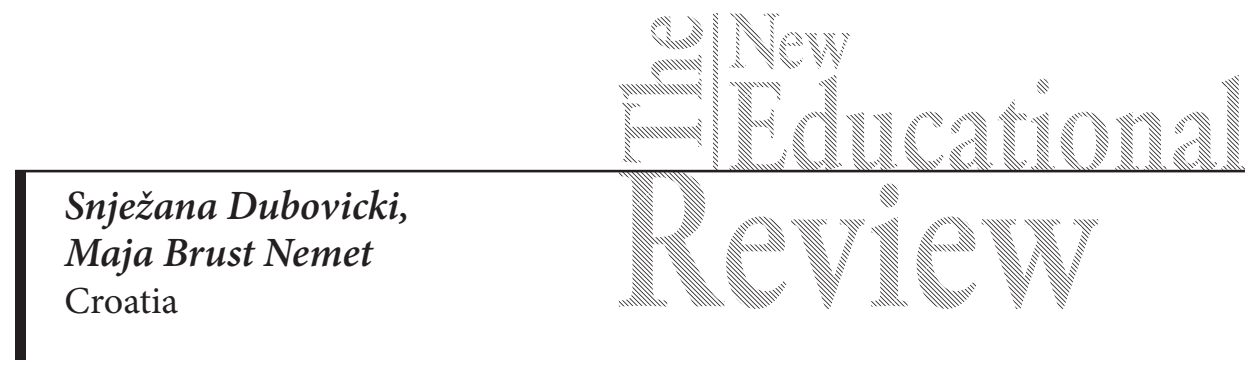

\title{
Self-Assessment of the Social Competence of Teacher Education Students
}

DOI: 10.15804/tner.2015.42.4.19

\begin{abstract}
Social competence (SC) is one of the most important competences required for successful performance of the teaching profession. Strengthening students' social and emotional competences provides aid and support for lifelong learning and social and emotional implementation of the teaching process.

By triangulating the results of a questionnaire, sociometry and interviews with students of teacher study, a significant level of social competence was observed. Students' sociometric status is not in full accordance with their self-assessment of SC, so more frequent are the allocations of popular students, but one rejected. SC is usually acquired in the family; college is placed in second place, which increases the importance of this issue in terms of intentional education.
\end{abstract}

Keywords: curriculum of teacher studies, students, social competence, sociometric status

\section{Introduction}

When talking about the teaching profession, social competences (SC) are among the basic most important ones for successful performance of this important profession. Therefore, it is important to research that issue at university level, among students being educated for the teaching profession. SC is usually defined as an ability to create and harmonize flexible, customized responses to demands and to create and exploit opportunities in the environment. According to this definition, socially competent individuals are those who can take advantage of incentives 
from the environment and their personal potential to achieve good development results (Katz \& McClellan, 1999). SC is an interactive process that promotes social values like interpersonal skills, pro-social behavior, an ability to make decisions (self-control), understanding others and self-confidence.

Theoretical starting points of SC are based on a postmodern paradigm (Previšić, 2002). From the pedagogical perspective, the SC concept implies education for the community, while the notion of unity stems from the dialectic of freedom of thought (Komar, 2010). According to the humanistic approach towards education, an education goal is not merely acquisition of knowledge, but holistic development of the individual with respect to his interests and needs, where besides intellectual also emotional development features are important, such as self-awareness, research and awareness of one's own emotions and motivations, social communication skills and pro-social behavior and development of satisfaction and pride. Social and emotional competences are important for understanding, managing and expressing the socio-emotional aspect in life due to successive management of life goals such as learning, establishing relationships, solving everyday problems and adjusting the complex requirements of progress and development (Jurić, 2010).

Brestan \& Eyberg, 1998; Patterson, DeGarmo \& Kuntson 2000; Webster-Stratton \& Taylor, 2001 already dealt with the encouragement and development of SC. Literature includes different theoretical models of SC, which condition different definitions of the said notion: Guilford \& Argylov, 1967; McFalolow \& Ford in 1982; Riggiov \& Marlovea 1986, Dodgeov 1987; Cavellov, 1990; Kazlauskiené, Ušeckiené, 2007 (according to Buljubašić-Kuzmanović, 2010). The term SC depends on the difference in its understanding. Therefore, there are authors who relate SC to ability (Vučić, 1981; Thorndike, 1920) and those who associate it with personality traits (Allport, 1937). Hargie, Saunders and Dickson (1981) define social skills as a set of inter-related social behaviors directed toward a goal, which can be learned and controlled by the individual. Goleman (1997) also identifies SC with emotional competence. Brdar (1993) equates the concept of SC with social and emotional intelligence, thus a possible relationship between social and academic intelligence is noted, but at least average intelligence is needed for a high social intelligence, whereas very high academic intelligence can even be a negative indication of social intelligence.

\section{Curriculum of social competence of students of teacher education}

The curriculum of SC studies is shown as an important contemporary component because it can reduce undesirable behavior and disturbances in the social 
life of the individual. The SC curriculum is based on socioconstrucitvism and sociocultural theory of development, which emphasizes that the development of people is strongly influenced by the social and cultural context. The SC curriculum should be focused on learning about acceptable behavior, sharing, exchange of ideas, asking questions, free expression of opinions, co-construction of study program, critical feedback, giving suggestions and comments, developing partnerships with others, and paying compliments. Such a curriculum takes into account all developmental, cultural and interpersonal differences and different approaches to learning so that it would leave room for individualized activities.

Research results (Markuš, 2010) show that encouraging the development of social competence has a positive effect on many areas of behavior and experience, it reduces the incidence of inadequate and risky behavior, significantly improves the quality of relationships with peers and adults, and there is a positive correlation of academic achievement and cognitive competences. Teaching students about the social (and emotional) skills, as one of essential characteristics of the development of social skills through friendship, empathy, cooperation, mediation, sharing and resolving conflicts, will allow for collaborative and partnership relations (Dubovicki, 2013). Peer interactions contribute to collaborative learning, management skills, impulse control of aggression and hostility, the development of prosocial behavior, they provide emotional security, love, affection, intimacy, solidarity and are a basis of all relationships. In the context of peer thinking, behavior patterns, lifestyles and value systems, young people achieve success increasing their sense of competence, self-confidence and autonomy as necessary preconditions of future teachers. Pedagogical and social implications of peer relationships are woven into the micro-pedagogical and social structure of educational institutions (Buljubašić-Kuzmanović, 2010).

\section{Research Problem and Research Focus}

This paper starts with defining students'SC as a set of skills that help to develop and maintain relationships, i.e. effective functioning in the social context. Development of social skills is facilitated by various educational programs of encouraging the SC as an important primary prevention strategy: development of emotional literacy (Goleman, 1997), providing empathy, developing communication skills, problem solving, success in school. Possession and development of social skills is one of the preconditions for creating a favorable emotional climate in the classroom, creating a stimulating environment for learning, so it can be concluded that students become more successful in their academic education with "progress" in 
social contacts (Bognar \& Kragulj, 2010). If educational institutions want to maintain and develop values and ensure students' holistic growth and development, they must go beyond teaching certain subjects. Traditional teaching has, in its conception and structure of teaching, regularly ignored the development of social skills and it focused on educational skills, while contemporary university classes encourage development of students' multidimensionalism.

\section{Research Methodology}

\section{General Background of Research}

The study was aimed at self-evaluation of SC of students of teacher education $(\mathrm{N}=180)$. It was conducted by triangulation, based on which result objectivity was to be achieved. To assess SC, a Likert-type scale was used (adapted from Katz \& McClellan, 1999), sociometric research and interview. For this reason, the empirical part of the paper was divided into three parts. In addition to the quantitative approach, the qualitative one was used to ensure better result interpretation, but also to move beyond the positivist approach in the research, adhering to the postmodernist and humanistic paradigms in education. During the study, research ethics was taken into account as well as and issues that did not infringe on individuals' intimacy.

The research aim was to obtain students' self-assessment of SC, determine students' social status and explore to what extent the university contributes to SC development. According to the mentioned objective, the following hypotheses were formulated:

H1 Teacher education students self-assess themselves as socially competent.

H2 The sociometric procedure does not determine "stars" and "rejected"ones.

H3 Students' attitudes are in favor of the university's contribution to developing social competence.

\section{Research Sample and Instrument and Procedures}

The study was conducted in 2014. It included a total of $\mathrm{N}=180(\mathrm{~F}=169, \mathrm{M}=11$, $M=22067)$ teacher education students. $1^{\text {st }}$ year students $(N=45)$ participated in the questionnaire (scale of social competence), 3rd year students $(\mathrm{N}=45)$ participated in the interview, and two groups of students ( $2^{\text {nd }}$ year, $\mathrm{N}=45$ and $5^{\text {th }}$ year $\mathrm{N}=45$ ) 
participated in the sociometric procedure. Research statistics were processed by SPSS version 19.0.

\section{Data Analysis and Research Results}

\section{Scale of social competence}

The starting point in creating the Questionnaire of social competence, which was developed for the research purposes, was the scale of social competence (Katz \& McClellan, 1997). The questionnaire was adapted to particles appropriate for students, and one particle was left. The original version of the questionnaire consists of 23 items. The reliabilities of the subscales were relatively high (alphas ranging from .68 to .71), the Cronbach alpha coefficient of reliability of the whole scale was determined as $\alpha=0.70$. The scale that was used in this study consists of 22 items divided into three sub-scales: 1 - students' Individual features, 2 -Social skills features and 3 - Peer relationships. When answering the questions, the respondents used the Likert-type scale of 5 degrees where 1 signified strongly disagree with the statement, and 5 fully agree with the statement. Table 1 provides the students self-assessment of SC explored through individual features.

Table 1. Individual features

\begin{tabular}{lcccccc}
\hline \multicolumn{1}{c}{ Claim } & N & Mean & Median & Sum & Variance & SD \\
\hline I'm not too dependent of adults. & 45 & 3.98 & 4.00 & 179.0 & 0.76 & 0.89 \\
\hline I usually volunteer and react. & 45 & 3.63 & 4.00 & 163.0 & 0.65 & 0.81 \\
\hline I cope accordingly with criticism & 45 & 3.98 & 4.00 & 179.0 & 0.75 & 0.87 \\
\hline I'm emphatic. & 45 & 4.36 & 5.00 & 196.0 & $\mathbf{0 . 9 3}$ & 0.96 \\
\hline $\begin{array}{l}\text { I maintain positive relationships with } \\
\text { colleagues, showing the ability of } \\
\text { genuine concern. }\end{array}$ & 45 & 4.56 & 5.00 & 205.0 & 0.35 & 0.59 \\
\hline I'm developing the sense of humor. & 45 & 4.40 & 5.00 & 198.0 & 0.48 & 0.69 \\
\hline I'm not lonely. & 45 & 4.56 & 5.00 & 205.0 & 0.57 & 0.76 \\
\hline I've a positive approach. & 45 & 4.60 & 5.00 & $\mathbf{2 0 7 . 0}$ & $\mathbf{0 . 3 4}$ & $\mathbf{0 . 5 8}$ \\
\hline
\end{tabular}

All the particles in subscale 1 have high values (3.63 to 4.60), while the particle "I have a positive approach" stands out by all values. It is extremely important to have a positive approach to SC because it relies on the quality of establishing 
social relations from which the educational process benefits. The claim with most deviations in the students' self-evaluation is "I'm empathic." Therefore, it can be concluded that in the educational process it is important to have, alongside SC, also professional competence and there is a question to what extent the teacher should be empathic towards students and vice versa.

Table 2 shows the results of subscale 2, relating to the students' features of social skills. The research results show that the students evaluated themselves as highly competent in all the particles (3.87 to 4.72). The particle that emphasizes the students' intercultural competence, which is closely related to SC "I accept the company of members of different ethnic groups," stands out.

Table 2. Features of social skills

\begin{tabular}{|c|c|c|c|c|c|c|}
\hline Claim & $\mathrm{N}$ & Mean & Median & Sum & Variance & SD \\
\hline $\begin{array}{l}\text { I clearly express wishes and preferences, } \\
\text { explain my actions. }\end{array}$ & 45 & 4.38 & 4.00 & 197.0 & 0.38 & 0.62 \\
\hline $\begin{array}{l}\text { I advocate my rights and needs appropri- } \\
\text { ately }\end{array}$ & 45 & 4.18 & 4.00 & 188.0 & 0.38 & 0.62 \\
\hline $\begin{array}{l}\text { I'm not easily intimidated by impulsive } \\
\text { colleagues. }\end{array}$ & 45 & 4.00 & 4.00 & 180.0 & 0.55 & 0.74 \\
\hline $\begin{array}{l}\text { I express anger and frustration without } \\
\text { harming others while doing so. }\end{array}$ & 45 & 3.87 & 4.00 & 174.0 & 0.76 & 0.87 \\
\hline I join activities. & 45 & 4.36 & 4.00 & 196.0 & 0.38 & 0.61 \\
\hline $\begin{array}{l}\text { I engage in debates about a current topic, } \\
\text { and contribute relevantly to a topic. }\end{array}$ & 45 & 3.96 & 4.00 & 178.0 & 0.59 & 0.77 \\
\hline I adjust easily and quickly. & 45 & 4.22 & 4.00 & 190.0 & 0.50 & 0.71 \\
\hline $\begin{array}{l}\text { I express interest and understanding of } \\
\text { others, ask for information from others. }\end{array}$ & 45 & 4.40 & 4.00 & 198.0 & 0.30 & 0.54 \\
\hline I negotiate and compromise. & 45 & 4.36 & 4.00 & 196.0 & 0.28 & 0.53 \\
\hline I don't draw necessary attention to myself. & 45 & 4.32 & 4.00 & 194.0 & 0.59 & 0.77 \\
\hline I accept company of different ethnic groups. & 45 & 4.72 & 5.00 & 212.0 & 0.26 & 0.51 \\
\hline I also communicate non-verbally. & 45 & 4.18 & 4.00 & 188.0 & 0.52 & 0.72 \\
\hline
\end{tabular}

Subscale 3, (Table 3) which explores peer relationships, also shows high self-assessment (4:01 to 4:05) of social competence. The third subscale results are especially significant because of the comparison with the results of research on sociometric status displayed below. 
Table 3. Peer relations

\begin{tabular}{lcccccc}
\hline \multicolumn{1}{c}{ Claim } & N & Mean & Median & Sum & Variance & SD \\
\hline & & & & & & \\
\hline I'm accepted by my colleagues. & 45 & 4.01 & 4.00 & 181.0 & 0.30 & 0.55 \\
\hline $\begin{array}{l}\text { Colleagues invite me to join in gatherings, } \\
\text { friendship, activities. }\end{array}$ & 45 & 4.05 & 4.00 & 182.0 & 0.59 & 0.77 \\
\hline
\end{tabular}

The results obtained from the research instrument confirm H1: Teacher education students self-asses themselves as socially competent. The students evaluated themselves as highly competent in all particles (particle values range from 3.63 to 4.72), which is considered a very desirable self-assessment.

\section{Students' sociometric status}

A sociometric structure of a study group includes the structure of affective relationships among members of the group, i.e. relations of attraction, which express general atmosphere as the indicator of study group cohesiveness. The $2^{\text {nd }}$ and $5^{\text {th }}$ year students were to single out three names based on sociometric criteria, which was a positive personal choice, i.e. desire to cooperate with three people selected. The condition for applying sociometry was the students' mutual understanding and spending time together. For the purposes of this research the students only chose positive votes. Figure 1 shows two sociograms of the $2^{\text {nd }}$ and $5^{\text {th }}$ year students.

The sociograms show the study groups' structure, in which interactions among the students are visible. After examining the $2^{\text {nd }}$ year sociogram (left) it can be seen that the majority of students were selected and there were no isolated students, two students received the highest number of votes (5), which puts them in the center of the concentrated circles. Students with most votes are called popular, stars of educational groups. It is evident that the students achieve mutual interactions and there are a lot of those who have 3 and 4 votes, who make unique groups within the group. On examining the $5^{\text {th }}$ year sociogram (right), it is evident that there are more popular students (8), and one student was isolated and not chosen for possible cooperation. So, both sociograms demonstrate popular students, or "stars". Although among the $2^{\text {nd }}$ year students there are no isolated or "rejected" students, there is one such person among the $5^{\text {th }}$ year students. Therefore, hypothesis H3: The sociometric procedure does not determine "stars" and "rejected" ones is refuted. 

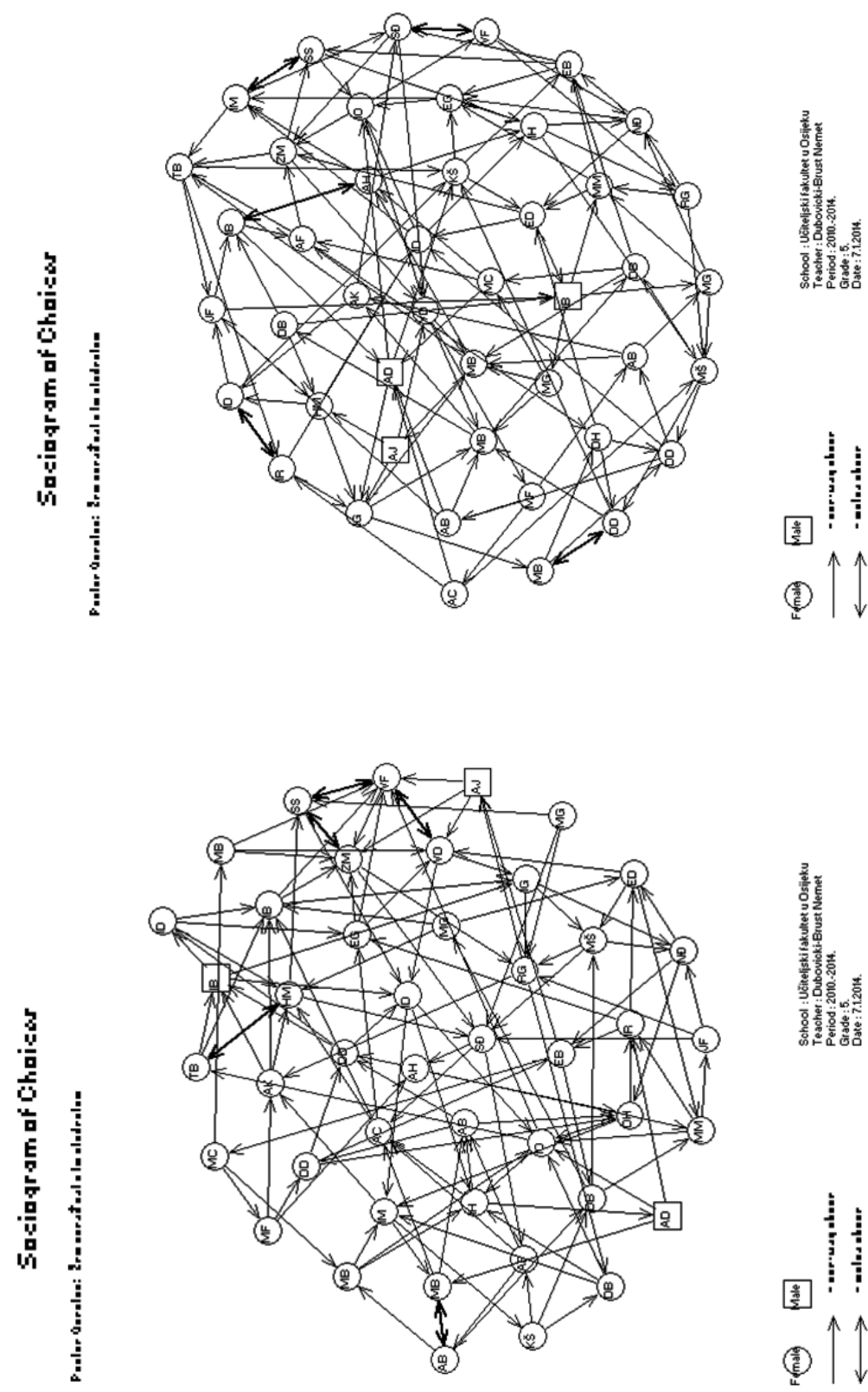

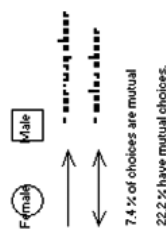

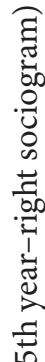

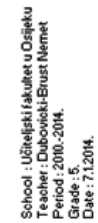


It can be concluded that although the students self-assessed themselves as socially competent (which is also evident in the results of the third group of questions in the above-mentioned instrument, where the students self-assessed themselves in relation to peers (1.4 to 5.4 ) as highly competent), the sociometric status of individual students (stars and isolated) says that it is not always so. It is assumed that the students generally considered themselves socially competent, but when it comes to individuals, they deviated from it.

\section{Interview of students' social competence}

The study used a semi-structured interview, aimed at establishing the understanding and definition of the respondents' SC, attitudes towards personal competence, as well as the importance of SC in relation to others; the place for acquiring $\mathrm{SC}$, the impact of university activities on the success of relationships with others, contribution of specific activities to SC development, the respondents' attitude towards relationships with others, and the respondents' suggestions concerning the possibilities of contribution of the Faculty to students' SC development.

The first question concerned the students' understanding of SC. $22.2 \%$ stated that SC was the ability to cope in social situations and understanding of self and others (relationship with others). $20 \%$ stated that the concept of SC was associated with communication skills, $13.3 \%$ that SC was adjustment of the individual to the environment, while 4 individual responses (each of 2.2\%) defined SC as follows: non-violent conflict resolution and tolerance, including skill sharing, support and understanding of others, knowledge and skills needed for coping in a particular social situation, and sociability. The respondents' answers show that they are aware of the importance of SC.

The next question referred to self-evaluation of SC. Both students of the $2^{\text {nd }}$ and $5^{\text {th }}$ years, as well as $1^{\text {st }}$ year students, in the above-mentioned survey, considered themselves socially competent (95.5\%), which confirms H1: Teacher education students consider themselves as socially competent.

The next question related to the place of SC acquisition (Figure 3). The largest percentage of the respondents claimed they acquired SC in their family (31.1\%), in college (24.4\%), among friends (22.2\%), in primary and secondary schools (11.1\%) and elsewhere (11.1\%). It is particularly interesting that if the percentage of 24.4 (related to the acquisition of competences in college) is added to the percentage of 11.1, which refers to the acquisition of SC in primary and secondary schools, the total is the percentage of 35.55 and therefore it can be concluded that education 
system in specified percentage contributed to SC development. The presented findings suggest partial acceptance of hypotheses H4 Students' attitudes are in favor of university contribution to SC development, given that most respondents claimed that family was the most responsible for SC development, while college is a second component.

We examined whether university activities influence successful relationships with others. $100 \%$ of the respondents said that various university activities affected their successful relationships with others, and this is the starting point for SC development of each individual. The next question referred to the students' perceptions of activities offered at the Faculty of Educational Sciences in Osijek contributing to the development of their SC. $82.3 \%$ responded that communication skills, developing cooperation (75.6\%) and tolerance (42.3\%), taking into account differences among students by teachers (31.1\%), developing empathy (28.9\%) and respect for rights and needs of students by teachers (26.7\%) mostly contributed to SC development.

Another question related to how the students see themselves in relation to others. Most of the respondents (53.33\%) thought they were accepted as members of their groups (study, seminars, work), but also that the majority of other students considered them to be friends (53.33\%). One part of the students estimated themselves as associates (15.56\%), and significant data shows that the students are happy when their mates achieve success (13.33\%). The results obtained by answering this question can also be compared to the results obtained with the help of sociometry and their sociometric status.

The final question referred to the respondents' opinions about the way the university could further encourage SC development. The research results show that the students mostly emphasize the importance of workshops (28.9\%), projects $(17.8 \%)$ and more group work (13.3\%) as primary contribution of the university's to SC development. A part of the students believed that group size (11.1\%), on which the quality of communication depends, had a great influence on SC development. The research results show that the students are willing to cooperate (8.9\%) with students (and teachers) from other faculties, but also that they see the need to restructure study programs (8.9\%), which should offer more elective courses that would develop students' SC.

The students' further responses indicate the importance of encouraging discussion and debate by professors, taking into account students' needs and rights and organization of different activities developing students' interests. 


\section{Discussion}

The students' definitions of SC largely overlap with the initial definition of this paper, which means that the students are informed about its importance and necessity. Triangulation shows that the students are more inclined to generally self-evaluate SC, which can be seen by examining the results of the questionnaires and interviews, while sociometry proved things to be a bit different compared to what the students presented in them. Frequent changes of teams will enable greater group cohesion and will thus strengthen the ability to work with all the students, which is especially important for the future workplace where new teams, necessary for co-operation, positive school culture and successful work, will be formed.

Family and the education system contributed to the students' total SC. It is important to emphasize that $100 \%$ of the students responded that various university activities affected their successful relationships with others, which should be our starting point on the path to teacher college curriculum reform. Although teacher education promotes students' SC development through its activities and teachers' methods of work, students' greater involvement in projects, collaboration with other schools and teachers, greater possibility of choosing elective courses and extracurricular activities and even greater interaction and activity in smaller study groups would help strengthen students' SC.

\section{Conclusions}

Guided by postmodern theoretical framework, as well as humanistic paradigm, SC is the foundation of building individual interests and needs. The curricula of teacher faculties should nurture encouragement of students' SC through content, learning outcomes and activities.

The study's scientific contribution is visible in the original instruments as well as in the approach to studying of this issue, based on which original results were obtained, and based on them the full SC picture was presented, from the teacher studies students' point of view.

Future research can explore SC of university professors. In addition, students' self-assessment of SC can be explored at different teacher education faculties in the world, and the results can be compared and presented with regard to the curricula of individual faculties in the framework of content and outcomes of individual courses. 


\section{References}

Allport, G.W. (1937). Personality: A psychological interpretation. New York: Holt.

Bognar, L. \& Kragulj, S. (2010). Kvaliteta nastave na fakultetu. Život i škola, 56(24), 169-182.

Brdar, I. (1993). Što je socijalna kompetencija? Godišnjak Zavoda za psihologiju, 2, 13-22.

Brestan E.V. \& Eyberg S.M. (1998). Effective psychosocial treatments of conduct-disordered children and adolescents: 29 years, 82 studies, and 5,272 kids. Journal of Clinical Child Psychology, 27, 180-189.

Buljubašić-Kuzmanović, V. (2010). Socijalne kompetencije i vršnjački odnosi u školi. Pedagogijska istraživanja, 7(2), 191-203.

Dubovicki, S. (2013). Povezanost kurikuluma učiteljskog studija i razvoja kreativnosti studenata. (Doctoral disertation). Zagreb: Filozofski fakultet.

Goleman, D. (1997). Emocionalna inteligencija. Zagreb: Mozaik knjiga.

Hargie, O., Saunders C. \& Dickson, D. (1981). Social Skills in Interpersonal Comunication. London: Croom Helm.

Jurić, V. (2010). Kurikulumski registar socijalnih kompetencija u društvenim i školskim okvirima. Pedagogijska istraživanja, 7(2), 177-189.

Katz, L.G., McClellan, D.E. (1999). Poticanje razvoja dječje socijalne kompetencije. Zagreb: Educa.

Komar, Z. (2010). Dijalektičko mišljenje kao mogući konstituens pedagogijskog pristupa kompetenciji. Pedagogijska istraživanja, 7(2), 269-280.

Markuš, M. (2010). Socijalna kompetentnost- jedna od ključnih kompetencija. Napredak, 151(3-4), 432-444.

Patterson G.R., DeGarmo D.S. \& Knutson N. (2000). Hyperactive and antisocial behaviors: Comorbid or two points in the same process? Development \& Psychopathology, 12, 91-106.

Previšić, V. (2002). Postmoderne paradigme u pedagogijskoj teoriji i praksi. In V. Rosić (Ed.), Odnos pedagogijske teorije i pedagoške prakse (pp. 56-63). Rijeka: Filozofski fakultet u Rijeci, 56-63.

Thorndike, E.L. (1920). Intelligence and its use. Harper's Magazine, 140, 227-235.

Vučić, L. (1981). Razvijanje shvatanja socijalnog odnosa kod učenika. Beograd: Zavod za udžbenike i nastavna sredstva.

Walker, E.W., Foley, J.M. (1973). Social Intelligence: Its History and Measurement. Psychological reports, 33, 839-861.

Webster-Stratton C., Reid M.J. \& Hammond M. (2001). Social skills and problem solving training for children with early-onset conduct problems: Who benefits? Journal of Child Psychology and Psychiatry, 42, 943-952. 